\title{
Ten Years in Rehabilitation of Spoil: Appearance, Plant Colonists, and the Dominant Herbivore
}

\author{
by \\ DAVID J. HAMBLER, PhD (London), \\ JEAN M. Dixon, PhD (Bradford) \\ $\&$ \\ William H.G. Hale, PhD (Southampton) \\ Honorary Senior Lecturer and Lecturers, respectively, \\ Department of Environmental Science, \\ University of Bradford, Bradford BD7 IDP, \\ England, UK.
}

\section{INTRODUCTION}

$\mathrm{G}$ razing mammals, throughout the world, affect the appearance and floristics of established vegetation. Grazing by Rabbits (Oryctolagus cuniculus) was regarded by Tansley (1949) as, apart from that of domesticated herbivores, 'perhaps the most widespread and effective biotic factor in modifying our [UK] semi-natural vegetation'. Their influence on such vegetation is usually beneficial in terms of Nature conservation value, and it cannot be reproduced by mowing (see Anderson \& Romeril, 1992).

However, the effects produced by Rabbits are, even now, comparatively poorly understood; they are progressive, patchy, and highly contingent - that is, dependent on the chance combination of circumstances in a given locality. They have usually been judged by comparison of 'before and after' states of established species-rich herbaceous vegetation in relation to a population crash or increase, or to exclosure and release from exclosure of areas of vegetation. Classic studies have involved comparison of islands with and without Rabbit populations. A number of Authors have referred to food preferences of Rabbits; these are neither constant nor universal, but have some bearing on the relative contributions of individual plant species in a community.

In this paper we report a continuation of a natural 'experiment' in which Rabbits have provided the overriding biotic factor on an area of pioneer vegetation. The complexity of this factor has been largely overlooked grazing by mammals, rather than their total activity, has dominated ecological thought. Exceptionally, Davis et al. (1993) have experimentally manipulated the access of Rabbits to plots with a variety of fertilizer treatments in sparse quarry-floor vegetation. Their results showed, unsurprisingly, that, at the end of a period of five years, any fertilizer combined with access (i.e. opportunity for both grazing and deposition of wastes) produced increased plant-cover. Further, an already ongoing increase in species-richness had been accelerated by this treatment, whilst simply preventing access by Rabbits, for all or part of each year, had eventually reversed the existing trend as their constraint upon potential dominants such as Arrhenatherum elatius (Oat-grass) was eased.

Clearly, effects of Rabbits on species-richness cannot be equated with grazing alone, nor reproduced by addition of inorganic fertilizer to a site on which Rabbits are already active. The influences of Rabbits (dung and urine deposition, selective grazing, trampling, scraping, transport of plant diaspores, etc.) are complex, localized, and probably experimentally inseparable. Positive effects upon plant growth may depend upon urine (which may, in some circumstances, be lethal), and upon the humic component of dung as well as upon its nutrient content. Plants in a pioneer quarry community may be dependent on both a net importation and redistribution of materials (including plant diaspores) by a variable Rabbit population.

In an earlier paper, we examined some effects of Rabbits on the anthropogenic pioneer vegetation of a reclamation site in England, UK (Dixon \& Hambler, 1993). We showed that grazing over the site as a whole was much less important than habitual, very local deposition of bodily wastes and localized grazing.

In the sparse vegetation, importation and deposition of nutrient-rich humic materials by Rabbits produced mesic 'islands', c. $1 \mathrm{~m}$ in diameter, with marked effects on the performances of sown grasses during the first few years after sowing. Visual inspection suggested that establishment and performances of forbs, sown with the grasses, and of various naturally immigrant species, might also be locally affected. Rabbits closely cropped the vegetation of these patches, which in view of their accumulations of dung pellets, and their progressive elevation, we called 'middens'; the 'latrines' of other writers do not always correspond with these.

The ultimate degree of persistence of Rabbits in their use of a given midden is not yet known; nor is the persistence, or importance of the effects, on the (changing) species composition of the vegetation as a whole.

We report here an extension of our observations, both in scope and in time, to 1994 - ten years after seeding. Our aims have been (a) to ascertain whether individual Rabbit middens continued long in use, and to record their effects on the appearance of the spoil's surface; (b) to follow and compare the performances of two sown grass cultivars and eight sown forbs, both on and off the original middens, and to test whether they might respond to an Autumn application of fertilizer; (c) to examine the contributions of other plants found in samples of middens and non-midden 'companion areas' (particularly of Senecio jacobaea (Ragwort) - the most conspicuously flowering species on the site between 1990 and 1992); (d) to relate the ecologies of these, and other species present, to Rabbit activity; and (e) establish the foregoing in the context of an expected increase in the number of immigrant species.

Our detailed observations on the localized changes attributable to the Rabbits are site-specific, and any seral 'end point' is far in the future. But it is only through eventual collation of experience from numerous similar industrial sites that comprehensive, and ultimately pre- 
dictive, understanding of biological processes involved in their ecological rehabilitation will be obtained.

We have therefore attempted to relate our observations to available autecological information, and to published work on the behaviour of Rabbits. We have sought to reconcile the performances and spatial distributions of some plant species (both sown and naturally immigrant) with categories proposed by Gillham (1955), and paraphrased thus: (a) Rabbit-avoided... seldom eaten; (b) Rabbit-resistant... favoured as food, but survival favoured by growth habit; or (c) palatable... favoured... but no morphological adaptation to withstand grazing. In addition we have sought explanatory coincidence between our observations and general theoretical biology - in particular in relation to the concept of 'plant strategies' (Grime, 1979).

Finally, acknowledging the stochastic nature of species immigration, the immediate constraint imposed by Rabbits on the performance of any 'unusual' plant, and the problematical course of succession, some consideration is given to a practical concern - the continuity of stages that are acceptable from both aesthetic and conservation viewpoints.

\section{Methods AND TEChNiques}

The site of these investigations was a north-facing limestone quarry-spoil slope (varying between $0^{\circ}$ and $30^{\circ}$ ) of shale and limestone fragments ranging in size down to dust particles (representative analyses in Hambler et al., 1990). The spoil was spatially heterogeneous - both at and beneath the surface, It was of $\mathrm{pH}$ around 8.2, and poor in plant nutrients (Hambler et al. loc. cit.; Dixon \& Hambler, 1993). The quarry is in Yorkshire, England, UK (National Grid Reference SE024533); the site is illustrated in Fig. 1. The practical aim of reclamation here was to produce lowmaintenance grassland with trees and shrubs, by-passing the long dicotyledon-dominated seral phase that is evident locally on ureclaimed spoil. Potentially dominating grasses should not oust sown forbs, or preclude immigration of species of conservation value.

The slope was graded, lightly manured, and seeded in 1984 (see Dixon \& Hambler, 1993) with a mixture of grasses: Red Fescue (Festuca rubra) cultivar BOREAL, and Creeping Bent (Agrostis stolonifera) cultivar PENNCROSS, with smaller amounts of the forbs listed in Table I. Native trees and shrubs were later planted as 'whips', and were judged to be too small and widely spaced to have, even by 1994, exerted detectable influence on the overall ecology of the site. The vegetation developed, during the first decade after sowing, into open species-poor grassland.

Quantitative records, related to the aims stated in our above Introduction, were made mostly in 1990 and 1991. The methods employed were opportunistic observation and recording to follow the course of the natural 'experiment' over the entire ( $c .3$ ha) slope. Middens and adjacent 'companion areas' were sampled within a $100 \mathrm{~m}$ x $60 \mathrm{~m}$ studyarea, comprising the bund cresting the spoil, a nearly level area, and part of the main slope (see Fig. 1); permanent sets of ten pairs were compared at intervals of time to provide some quantifiable information. The companion area immediately adjacent to each midden was defined spatially by

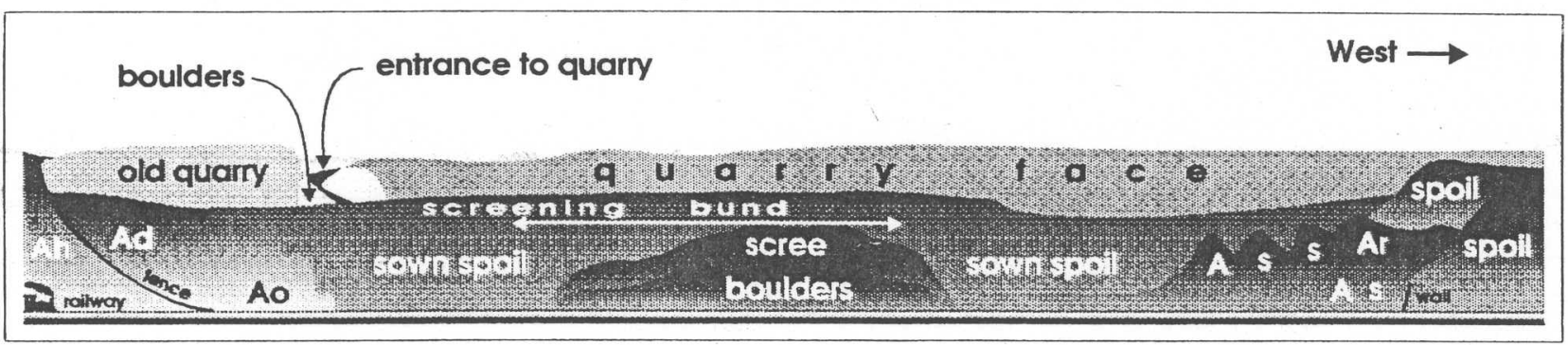

FIG. 1. 'Sketch' (not to scale) illustrating the topography and surroundings of the north-facing spoil-slope seeded in 1984. The east to west dimension of the area shown is $0.5 \mathrm{~km}$; the vertical height of the spoil in the centre of the sketch is approximately $25 \mathrm{~m}$. The low bund at the summit of the spoil screens a 'stone haul' road and a deep working-quarry; it is backed by boulders (shelter for Rabbits). Arrows encompass the 'study area' on a nearly flat zone below the bund. Ah= ancient grassland used by horses; Ad = ancient disturbed grassland; Ao = ancient grassland with overspill of spoil; As = ancient thinly-scraped grassland; Ass = ancient heavily-scraped grassland; Ar = ancient grassland relic . Behind the railway, along at the foot of the spoil, lies Haw Beck, a stream that is fringed in parts by a small seasonal swamp.

TABLE I

Forbs Sown with Grasses in 1984, their 'Strategies', and Survival in 1991.

\begin{tabular}{|c|c|c|c|}
\hline & To Rabbits & Strategy & Habit \\
\hline Achillea millefolium (Yarrow)* & $\mathrm{pr}$ & $\mathrm{R}-\mathrm{P}$ & creeping \\
\hline Anthyllis vulneraria (Kidney-vetch) & pnr & $\mathrm{C}-\mathrm{S}-\mathrm{R}$ & creeping \\
\hline Centaurea nigra (Lesser Knapweed)* & pnr & C-S-R & multiple rosettes \\
\hline Leucanthemum vulgare (Ox-eye Daisy)* & pnr & $\mathrm{C}-\mathrm{S}-\mathrm{R}$ & short rhizome \\
\hline $\begin{array}{l}\text { Lotus corniculatus } \\
\quad \text { (Common Birdsfoot-trefoil)* }\end{array}$ & $\mathrm{pr}$ & $\mathrm{C}-\mathrm{S}-\mathrm{R}$ & prostrate or erect (depending on genotype) \\
\hline Plantago lanceolata (Ribwort Plantain)* & pnr & $\mathrm{R}-\mathrm{P}$ & several rosettes \\
\hline Sanguisorba minor & & & \\
\hline subsp. minor (Salad Burnet)* & pnr & C-S-R & rosette \\
\hline Trifolium repens (White Clover)* & pr & $\mathrm{R}-\mathrm{P}$ & creeping \\
\hline
\end{tabular}

$\mathrm{p}=$ palatable, $\mathrm{r}=$ resistant, $\mathrm{nr}=$ non-resistant, to Rabbits:

* Species surviving on the reclaimed site between 1984 and 1994. Strategies, according to Grime $(1979): \mathrm{R}=$ ruderal; $\mathrm{P}=$ perennial;

$\mathrm{C}=$ competitor; $\mathrm{C}-\mathrm{S}-\mathrm{R}=$ species with 'characteristics intermediate between those of the competitor, the stress-tolerator, and the ruderal'. 
means of a steel chain arranged, when required, to replicate the midden's form (see Dixon \& Hambler, 1993).

Samples of spoil taken, avoiding middens, from a 400 $\mathrm{m}$ plot on a slope of $c .30^{\circ}$ which had been surface-treated with fertilizers (ammonium nitrate $[34.5 \% \mathrm{~N}]$ and ' $\mathrm{P}_{2} \mathrm{O}_{5}$ ' each at $1,250 \mathrm{~kg} / \mathrm{ha}$ ) in September 1990, and from an adjacent untreated plot, were subjected to standard soil analysis techniques (Allen et al., 1974) for estimation of extractable phosphorus and nitrogen. These analyses were carried out at intervals in 1990 and 1991.

The surface stonyness of comparable areas was assessed by counting the number of visible stones in a block of sixteen $100 \mathrm{~mm}$-square quadrats.

Percentage plant cover was used as a means of assessing the performances of sown grasses. It was determined by means of a pin frame, with ten vertical pins, which was moved systematically over a given area: only the first species touched by a lowered pin was scored. Subdivided one-metre-square quadrats were used for estimations of rooted frequency.

Species-richness of middens, companion areas, and long-established plant communities nearby, was judged from counts of species within whole one-metre-square quadrats placed centrally upon middens and their companion areas, and at random within other vegetation; or alternatively from counts in which entire middens and their companion areas constituted the spatial units to be compared.

An abundantly seeding species, Senecio jacobaea, was chosen to test the specific validity of the subjective observation that a midden provides not only a spatially-defined microhabitat affecting the establishment and maturation of some plants, but that it is itself concentrically zoned. The role of middens in the demography of $S$. jacobaea was investigated through a survey of ten middens and their companion areas in the summers of 1991 and 1992.

Each of the middens and its companion area was sampled by means of a one-metre-square quadrat divided into 100 units. The axes of the quadrat were orientated E-W and N-S, and it was placed centrally on the midden or companion area, and subdivided, as shown in Fig. 2, into equal areas representing outer and inner zones in different proportions. Counts of seedlings were made in these zones. The sizes of rosettes were estimated from the length of the longest leaf in the rosette, and the positions of individuals were plotted to allow determinations of their distances from the centre of the quadrat (i.e. of the midden or companion area). The number of flowers or capitula* borne by adult plants on the middens was recorded, in 1991, as a measure of their reproductive potential; similar records from plants within a $5 \mathrm{~m}$ radius of each companion area were obtained for comparison.

\section{Results, OBSERVATIONS, AND Discussion}

\section{Plant-nutritional Status of Spoil in Relation to Grass Cover}

The data presented in Table II for a plot representing the generality of the spoil indicate a continuity in the plantnutrient deficiencies recorded in previous papers. They also show (a) that available nitrogen was rapidly returned

* Heads of flowers or florets characteristic of this Daisy Family (Compositae). - Ed.

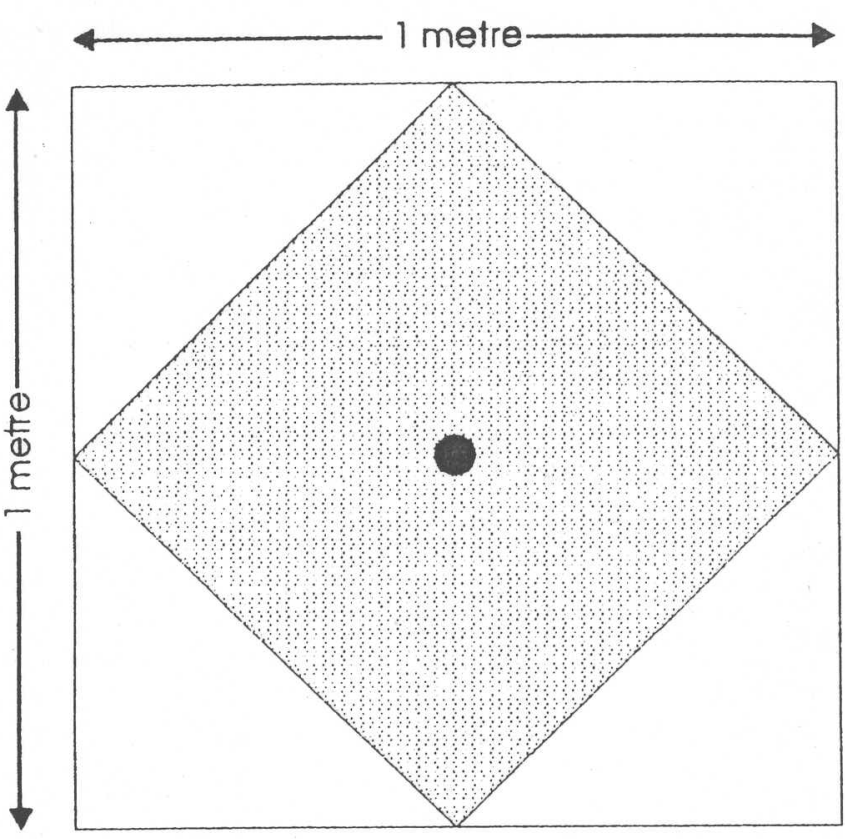

FIG. 2. Inner and outer zones of a midden samplea by means of a quadrat: the spot represents the centre of the midden, of which shaded and unshaded areas provide samples with a central and a peripheral bias, respectively.

\section{TABLE II}

Quantities of Extractable Phosphorus and Nitrogen in Samples from $400 \mathrm{~m}^{2}$ Spoil Plots After Surface Treatment With Fertilizers in September 1990.

\begin{tabular}{llll}
\hline Date & Untreated Spoil & Treated Spoil & Ratio \\
\hline 2.11 .90 & P $0.27[0.02]$ & $3.91[1.54]$ & $1: 14$ \\
& N $0.04[0.001]$ & $0.09[0.01]$ & $1: 2.25$ \\
16.4 .91 & P not recorded & $2.82[0.48]$ & - \\
& N not recorded & $0.03[0.01]$ & - \\
26.7 .91 & P $1.63[0.07]$ & $4.46[0.87]$ & $1: 3$ \\
& N $0.04[0.01]$ & $0.05[0.01]$ & $1: 1$ \\
\hline
\end{tabular}

Data represent means from random samples; figures in square brackets are standard errors: $\mathrm{P}$ is measured as $\mathrm{mg} / 100 \mathrm{~g} ; \mathrm{N}$ as a percentage. Nitrogen was applied as ammonium nitrate $(34.5 \% \mathrm{~N})$ and phosphorus as $\mathrm{P}_{2} \mathrm{O}_{5}$.

to its original level (c. $0.04 \%$ ) after being boosted in 1990 to around twice this level by surface application of ammonium nitrate, and (b) that an increase in extractable phosphorus was more lasting. Despite an increase (possibly microbially mediated) of the latter in the untreated area, the value remained within the 'medium range' $(0.2$ to $2 \mathrm{mg} /$ $100 \mathrm{~g}$ ) for mineral soils reported by Allen et al. (1974); and the highest value $(1.6 \mathrm{mg} / 100 \mathrm{~g})$ approximated that recorded one year previously for midden soil (Dixon \& Hambler, 1993).

Subjective assessment suggested that the grass cover of the plot treated in 1990 did not differ from that of the rest of the spoil throughout the period of 1990-94. This is consistent with the proposition that combined nitrogen remained the limiting factor for plant growth on parts of the spoil which remained unpatronized by Rabbits ten years after reclamation was initiated. 


\section{Appearance of the Site: Plant Cover \& Stoniness}

Stoniness adversely affected the appearance of the site, and was inversely related to plant cover. It was assessed (Table III) as a good indicator of the 'success' of the pioneer vegetation in improving the appearance of the site in the fifth and sixth years after germination of the sown grasses. The data show that middens were consistently far less stony than their companion areas, and suggests that whilst the appearance of the companion areas changed little during the period from May 1990 to August 1991, that of the middens improved; the improvement was attributable to overgrowth by plants (mainly by the sown grasses - see Table IV) of the numerous surface stones.

TABLE III

Mean Occurrence of Stones on Middens (M) and Companion Areas (C)

\begin{tabular}{llcr}
\hline & $M$ & $C$ & Difference \\
\hline May 1990 & 9.8 & 15.8 & $6.0 * * *$ \\
August 1991 & 2.2 & 15.6 & $13.4 * * *$ \\
Difference & $7.6 * * *$ & $0.2 \mathrm{NS}$ & \\
\hline
\end{tabular}

Data $=$ number of $10 \mathrm{~cm}$ quadrats with a visible stone.

$* * * \mathrm{p}<0.001$ : difference significant (by unpaired t-test). NS $=$ not significant.

The general appearance of the site, and of the middens in particular, varied progressively, episodically, and seasonally. Thus in the wet spring of 1991 the somewhat barren (but progressively improving) appearance of the reclamation site was ameliorated by a degree of 'greening' it had not previously attained. By Autumn, the sward near to the centre of most of the middens was more intensely green than that situated peripherally - suggesting targeting by the Rabbits of their nitrogen-rich urine. During the following Summer (June 1992) the centres of the middens were again found to be of a darker green then their surrounding areas, whilst peripherally some middens showed yellowing of their grass-shoots - presumably as a result of drought.

During each Spring and Autumn a nitrophilous moss, Brachythecium rutabulum, was abundant on middens, where it usually contributed to a bright-green marginal zone, and sometimes to the greening of internal patches. Off the middens, small stress-tolerant mosses, including Barbula ungiculata and Grimmia apocarpa, contributed little to the cover or to the general appearance of the spoil. By Summer 1994 the whole site appeared green from a distance, although the plant cover remained incomplete, and the middens were still distinguishable.

\section{The Sown Grasses, Plant Cover, and Rabbits}

The ecological strategies of the two sown grass species differ: Festuca rubra (Red or Creeping Fescue) is described by Grime (1979) as a 'stress-tolerant competitor' - combining an ability to survive conditions of limited nutrient availability with a capacity for lateral vegetative spread during a favourable period. In contrast, Agrostis stolonifera (Fiorin) is a stoloniferous perennial described as a 'competitive ruderal' - with a propensity to occur in infrequently disturbed habitats of high productivity. Its roots do not penetrate as deeply as those of $F$. rubra (Fig. 3, F.r). Both are eaten by Rabbits, but the former appears either to be less favoured or to produce new whole leaves more rapidly between grazing episodes. In a mixed pioneer community, Rabbits might be expected to modify the grasses' competitive relationship.

TABLE IV

Presence and Percentage Top-cover of Plant Species on 6 June 1990.

$\mathrm{M}=$ Middens $; \mathrm{C}=$ Companion Areas; abbreviated names in full at end.

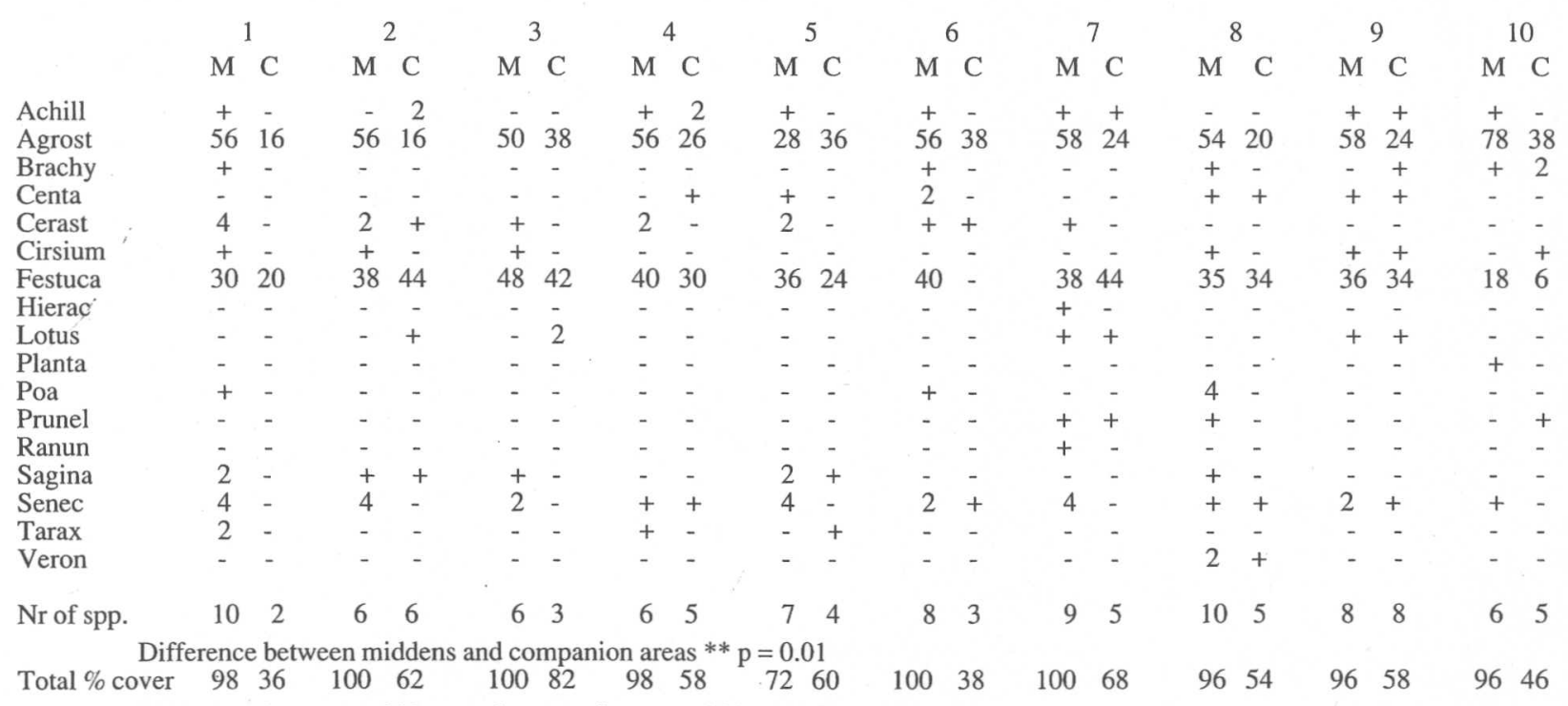

Difference between middens and companion areas $* * * \mathrm{p}=0.001$

Notes: Statistical conclusions are from unpaired t-tests. Species present but not recorded by pin frame are denoted by + .

Names of plants: - Achillea millefolium, Agrostis stolonifera, Brachythecium rutabulum [a moss], Centaurea nigra, Cerastium fontanum, Cirsium vulgare, Festuca rubra, Hieracium vulgatum, Lotus corniculatus, Plantago major, Poa annua, Prunella vulgaris, Ranunculus repens, Sagina procumbens, Senecio jacobaea, Taraxacum officinale, Veronica serpyllifolia [Nomenclature here and elsewhere follows that of Clapham, Tutin \& Moore (1987) for flowering-plants, and Smith (1980) for the moss.] 


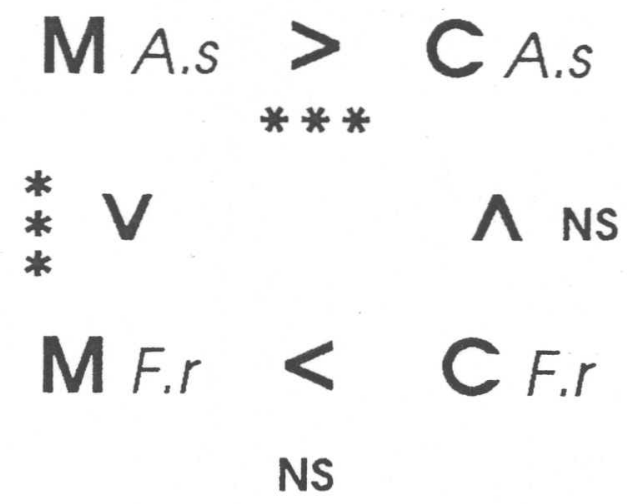

FIG. 3. Relationships between cover values for Agrostis stolonifera (A.s), and Festuca rubra (F.r) on middens (M) and companion areas (C) > = greater than; asterisks indicate significance of differences by t-test.

A measure of the 'quantity' of vegetation - the standing crop - was shown to be greater on the middens than elsewhere on the spoil five years after sowing (Dixon \& Hambler, 1993). A different measure, percentage plant cover, almost a year later still, was also greater. Together, the sown grasses provided by far the greatest contribution to cover both on and off the middens ( $c f$. Table IV). Relationships between the cover values of the two species on and off middens are summarized in Fig. 3; this shows that an effect of Rabbit patronage had been to stimulate $A$. stolonifera (A.s) whilst any such effect on $F$. rubra was insignificant, overridden perhaps by competition.

Inflorescences of $A$. stolonifera were produced each year from 1991 onwards; they were generally absent except on the middens, where they were prostrate, until 1994 when more general flowering was apparent; the early absence was a presumed outcome of unrelieved nutrient stress on an unadapted species. Festuca rubra had succeeded in flowering on the spoil some years previously, but no inflorescences were found on the developing middens. This species has 'never been seen to flower when grazed'; Gillham's (1955) comment referred to swards on the island of Skokholm, Wales, but is apt also here - see below under '10. Rabbit Behaviour: Its Relevance to Spoil Rehabilitation’.

\section{The Sown Forbs as Colonists}

Being derived from commercial seed of unknown provenance, any introduced species cohort might not be well adapted to local conditions. Any cohort is subject to decline in numbers, and it was not possible to determine, for any one of the sown species, whether a decline, detected subjectively, was Rabbit-mediated. It was hoped that sexual reproduction would eventually allow numerical increase in the populations of each of the sown species, and production of recombinant biotypes* better adapted to the habitat. Some behavioural pattern or patterns of Rabbits may well have been inimical to both the increase and evolution of every one of the sown species during the first decade.

All of the sown forbs ( $c f$. Table I) had been expected to persist on the spoil, with the five $\mathrm{C}-\mathrm{S}-\mathrm{R}$ strategists performing well, and the three ruderal perennials surviving

\footnotetext{
* Presumably by cross breeding with native wild strains. — Ed.
}

sub-optimally — that is, initiating a 'tolerance model' (see Usher, 1979) succession. Lack of resistance to Rabbitgrazing, and certain behavioural patterns of Rabbits, may be assumed here to be responsible for the complete failure of Anthyllis vulneraria (Kidney Vetch) and the relative lack of success of Centaurea nigra (Lesser Knapweed), Leucanthemum vulgare (Ox-eye Daisy), and Sanguisorba minor (Salad Burnet), evident from Table IV, where only two of the eight sown forbs are represented.

Two creeping species, Achillea millefolium (Yarrow) and Trifolium repens (White Clover), both regarded by Grime (1979) as ruderal perennials, survived on the spoil; but the Trifolium, judged subjectively to have declined in frequency, was not detected by sampling ten years after sowing ( $c f$. Table IV). Thus two species with the same 'strategy', each reputedly Rabbit-resistant, differed in their success. Further, the ability of $T$. repens to fix atmospheric nitrogen also proved irrelevant to its survival here.

A. millefolium is well-represented among the paired midden/companion records of presence ( $c f$. Table IV). It even made a small contribution to the cover estimate of two companion areas, whilst some clones on middens became vigorous enough to produce runners (Fig. 4, A.m). There was a complete absence of its erect inflorescences on the spoil until 1989, when one was found - on a midden, protected among the spiny leaves of a Spear Thistle

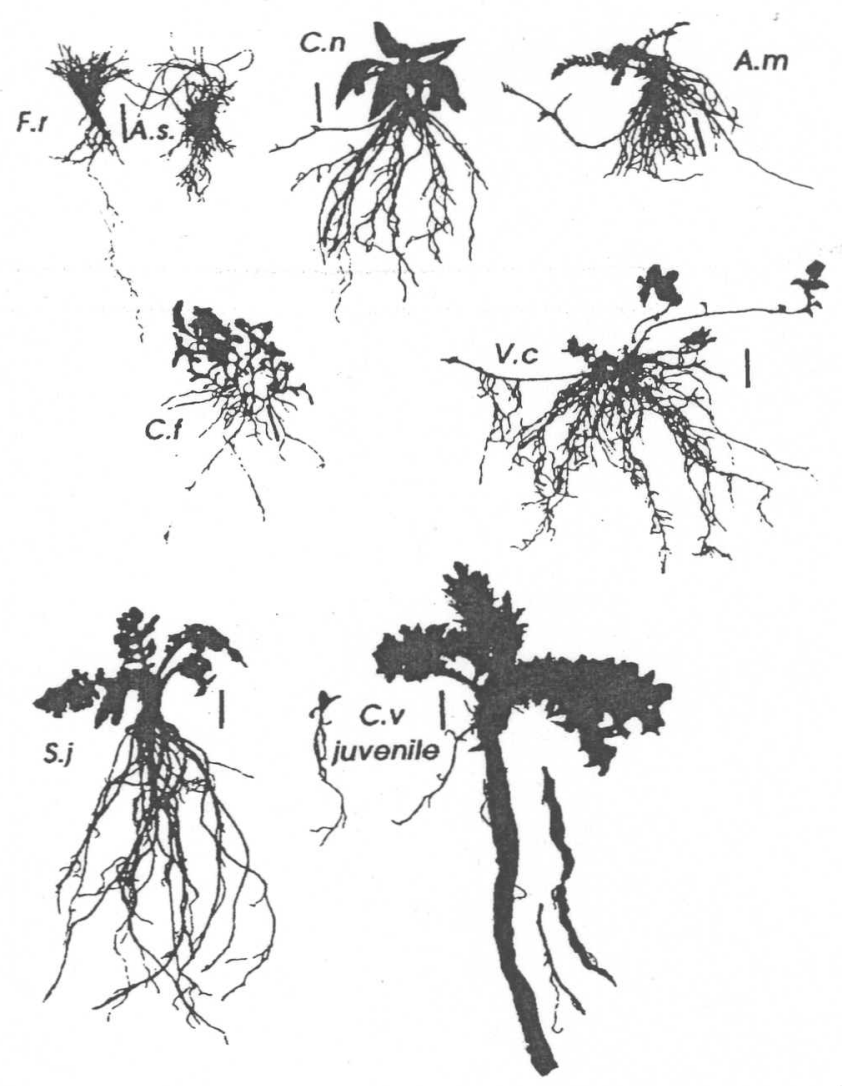

FIG. 4. Plants from middens: root systems excavated 26.4.91. A.s = Agrostis stolonifera; $C . n=$ Centaurea nigra; $C . v=$ Cirsium vulgare; $F . r=$ Festuca rubra; $S . j=$ Senecio jacobaea; $V . c=$ Veronica chamaedrys; A.m = Achillea millefolium and $C . f=$ Cerastium fontanum (see text). Bars to give scales represent $20 \mathrm{~mm}$. 
(Cirsium vulgare); this suggests that Rabbit-grazing rather than nutrient stress had reduced its reproductive potential on middens. The status of this otherwise palatable plant as an 'indicator of severely grazed... areas' (Gillham, 1955) was subjectively apparent by 1994 , when extensive clones had developed on middens, and unprotected inflorescences were found on the site for the first time.

Adaptation to local conditions has been shown to be important for populations of Plantago lanceolata (Ribwort Plantain) by Tienderen \& Toorn (1991). Lack of such adaptation, together with non-resistance to Rabbit-grazing, could account for the infrequency of this species ( $c f$. Table IV); that nutritional deficiencies do not preclude its survival was shown by the presence of flowering individuals of this ruderal perennial in 1994.

Likewise, Lotus corniculatus (Common Birdsfoottrefoil) is far from being an ecologically homogeneous species (see Jones \& Turkington, 1986). Of all the flowering-plant species (sown and unsown) recorded by the quantitative techniques, only $L$. corniculatus contributed more to the cover on a companion area than on any midden. As a Rabbit-resistant (Gillham, 1955), C-S-R strategist (Grime, 1979), able to fix nitrogen (plants here were nodulated), its vegetative persistance throughout the spoilheap for all of the ten years after sowing is explicable.

In an experiment by Davis et al. (1993), lasting four years, on an already species-rich limestone quarry-floor, addition of fertilizer resulted in a $57 \%$ increase in rooted frequency of the Birdsfoot-trefoil; this was far above a general continuing increase of $21 \%$, and an increase of $24 \%$ with exclusion of Rabbits for the entire period. Such observations, as well as our own, suggest that Rabbits will generally have little effect on the contribution of this species to natural or induced early seral communities on recently-abandoned calcareous wastes and in the pastures where it is said, by Jones \& Turkington (1986), to benefit from 'a moderate to severe level of grazing by rabbits'.

The failure of the sown Birdsfoot-trefoil cohort to produce flowers on the reclaimed spoil has not yet been explained, although Rabbits are likely to have removed potentially-flowering axes from middens (as with Festuca rubra). Natural populations have flowered abundantly in the adjacent relict grassland ('As' in Fig. 1) over scraped soil, and less than $1 \mathrm{~km}$ away in black humic soil on an abandoned quarry-floor. The habitats of $L$. corniculatus include pastures and grassy places (Clapham et al., 1987); a respite from the attentions of Rabbits might permit its increase through seeding in the developing grassland.

Centaurea nigra was found to be preferentially grazed by Rabbits in a short turf grassland by Bhadresa (1987), and its erect inflorescences are particularly vulnerable. It was present throughout the first decade both on and off the middens ( $c f$. Table IV). It is a C-S-R strategist surviving through its branched rootstock (Fig. 4, C.n); the size of rosettes in 1994 was very variable, and it might have been that not every plant belonged to the cohort germinating in 1984-5. It was not observed in flower until 1994, although the critical size for flowering, exemplified by a specimen with a bitten-off influorescence found in 1991, had long been attained by some plants. A respite from grazing for even one Summer might allow this species to exploit the site more effectively through seeding.

\section{Species-richness}

The results of a comparison of plant species-richness in a sample of ten middens, and their companion areas, in 1990 were presented as Table IV; they show that five years after reclamation commenced, the middens were richer in species (with a mean number of 7.5 per entity) than the companion areas (with a mean number of 4.6).

Species-richness of middens and companion areas was compared with nearby ( $c f$. Fig. 1) longer-established vegetation stands in 1991. Although the substratum beneath each of the older stands is the native calcareous brown-earth soil, it had been variously disturbed: in area 'As' the soil profile had been truncated, by scraping off a few centimetres of its humic horizon, during landscaping in 1981; the respective disturbances to 'Ad' and 'Ao' had occurred decades previously through unspecifiable activity around a quarry-lip, and through a shallow overspill of spoil.

The mean numbers of flowering-plant species recorded (Table V) show that six years after reclamation commenced the spoil, as a whole, remained poorer in species than the surrounding vegetation. The midden vegetation appeared richer than that of the companion areas, but the difference was not statistically significant.

\section{Immigrant Species Detected by Sampling in 1990: their Strategies and Interactions with Rabbits}

A sample of ten middens and ten companion areas studied in 1990, was too small for the presence of any but the most abundant plants on the spoil to be unfailingly recorded. Although no species could be regarded as confined either to middens or to companion areas, there are suggestions of some affinities ( $c f$. Table IV). The strategy and habit of each of the immigrant species detected during sampling on any midden, and quotations relating it to Rabbit-grazing, are set out in Table VI. From this Table it is evident that the majority of abundant species seven years after the spoil slope was graded, were ruderal perennials rather than the stress-toleraters and $\mathrm{C}-\mathrm{S}-\mathrm{R}$ strategists which might be hoped for as early colonists of nutrientpoor spoil. The establishment of ruderal perennials may be attributable to a lack of competition in the open community.

TABLE V

Mean Number of Species of Flowering-plants in $1 \mathrm{~m}^{2}$ Quadrats in Locations shown on Fig. 1.

\begin{tabular}{cllcc}
\hline Designation on Fig. 1 & \multicolumn{1}{c}{ Location } & Description of Vegetation & Mean Nr of Species & Number of Quadrats \\
\hline As & North foot of spoil & Grassy, over scraped soil & 19.8 & 5 \\
Ad & East flank of spoil & Grassy, on disturbed quarry-lip & 17.4 & 5 \\
Ao & East flank of spoil & Grassy, on natural soil with thin spoil overspill & 14.6 & 5 \\
Study area & Spoil & Grassy (middens) & 8.3 & 10 \\
Study area & Spoil & Grassy (companion areas) & 5.9 & 10 \\
\hline
\end{tabular}

Statistical assessment: LSD 2.967. $\mathrm{p}=0.001$. 
The Relationship with Grazing Rabbits, 'Strategy', \& Habit of all Immigrant Plant Species Recorded at least Once on the Ten Middens (of Table IV) Searched in June 1990.

(Rabbit relationships in quotation marks are inferred from the literature [see text]; Strategies after Grime (see footnote to Table I), Habit assignments based on observation and descriptions in standard floras.)

\begin{tabular}{llll}
\hline Species & Rabbit Relationship & Strategy & Habit \\
\hline Brachythecium rutabulum & ungrazed & R-P & creeping hypnoid moss \\
Cerastim fontanum & 'avoided' & R-P & short-lived, creeping \\
Cirsium vulgare & young rosettes and fls eaten & R-B & rosette, monocarpic \\
Hieracium vulgatum & avoided? & $\mathrm{C}-\mathrm{S}-\mathrm{R}$ & rosette perennial \\
Plantago major & avoided? & $\mathrm{R}-\mathrm{P}$ & annule rosette \\
Poa annua & 'avoided' & $\mathrm{R}-\mathrm{A} / \mathrm{P}$ & rhizomatous \\
Prunella vulgaris & 'palatable resistant' & $\mathrm{C}-\mathrm{S}-\mathrm{R}$ & serennial grass \\
Ranunculus repens & 'palatable resistant' & $\mathrm{R}-\mathrm{R}-\mathrm{P}$ & rosette with prostrate rooting laterals \\
Sagina procumbens & ungrazed here & $\mathrm{R}-\mathrm{B} / \mathrm{P}$ & single rosette \\
Senecio jacobaea & 'avoided' & $\mathrm{R}-\mathrm{P}$ & single rosette \\
Taraxacum officinale agg. & 'unfitted to withstand grazing' & $\mathrm{S}-\mathrm{R}-\mathrm{A} / \mathrm{P}$ & shortly creeping \\
Veronica serpyllifolia & ungrazed here & &
\end{tabular}

Key: $\mathrm{C}$ = competitive, $\mathrm{R}=$ ruderal, $\mathrm{S}=$ stress-tolerant, $\mathrm{A}=$ annual, $\mathrm{B}=$ biennial, $\mathrm{P}=$ Perennial.

Brachythecium rutabulum is a perennial pleurocarpous moss of fertile habitats. It was the only moss that was conspicuous on the spoil during the first decade. The quantitative results (see Table IV) obtained in Summer, differed from our regular visual assessment of its greater contribution to midden vegetation in the colder months. This is entirely explicable through the results of Furness \& Grime (1982), who refer to its large amplitude of seasonal change in biomass, its capacity to grow at low temperatures, and its ability to co-exist with productive vascular plants. It formed mats only on middens, and was thus an indicator of mesic conditions.

The records of Table IV are unreliable as guides to the importance of this moss in the pioneer ecology of the spoilheap. Indeed it is a safe assumption that, as the seasonal peaks of productivity of mosses and grasses alternate, the mutually sustaining cycle of nutrients, via soil organisms, described by Tooren et al. (1988), occurs here. The frequent predominance of $B$. rutabulum around midden margins is explained by its 'active foraging behaviour' - that is, through concentration of its shoots in patches where the light is bright (Rincon \& Grime, 1989).

It is unlikely that a moss would be ingested, except by accident (Bhadresa, 1987). Scuffing by Rabbits could distribute vegetative fragments - to survive, perhaps briefly, around a midden ( $c f$. Table IV). Abundant capsules produced each Autumn, and regeneration from fragments, must increase the likelihood of exploitation of practically all gaps on the spoil.

A moss cover is expected to have an important effect, either negatively or positively, on the establishment of seedlings of some potential colonists (Keizer et al., 1985): the fringes of middens seem to be particularly hospitable to Ragwort (see below).

Cerastium fontanum subsp. triviale (Common Mouseear Chickweed) contributed a small percentage to the cover assessment on four of the ten middens that were sampled, and was present on another. Plants in two of the companion areas, and elsewhere in the open vegetation, were small, whilst on middens individuals were luxuriant and flowered freely. This ruderal, short-lived perennial was disliked by, but formed part of the diet of, Rabbits in the grassland studied by Bhadresa (1987), and it is a "very common plant of mesotropic grassland...' (Clapham et al., 1987); it was dependent here on the Rabbits, and (see Fig. 4, C.f) showed no sign of being grazed.

Cirsium vulgare (Spear Thistle) occurred throughout the spoil, but was found more frequently on middens than on companion areas ( $c f$. Table IV). Some rosettes eventually developed a long tap-root (Fig. 4, C.v) which penetrated far below the humus-enriched midden surfaces. These may be vulnerable to mechanical damage by Rabbits, as are flowering stems which may be felled, and the capitula which are sometimes browsed. An excess of rosettes over flowering individuals in any year, both on and off middens, reflects the generally high mortality reported by Klinkhamer \& Jong (1993). Such mortality here is possibly due partly to grazing, as those Authors report that leaves are grazed by Rabbits in Winter.

This competitive ruderal species includes fields and waste places among its habitats (Clapham et al., 1987), and has already demonstrated its ability to reproduce on the site (numerous seedlings have been found around old flowering stems on middens); it will undoubtedly persist throughout any sub-scrub seral stage (see Klinkhamer \& Jong, 1993) on the spoil.

Hieracium vulgatum (Hawkweed) is an abundant stress-tolerant ruderal species 'of rocky and grassy places' (Clapham et al., 1987). Its sparse rosettes were found generally distributed on the spoil for a number of years prior to 1990 when it was recorded in the sample of middens. It occurs as part of the dicotyledon-dominated seral stage on older spoil-heaps on which it flowers freely in the vicinity. As a sparsely-hairy plant it may not be relished by Rabbits - but although no grazed rosettes were detected, neither were inflorescences during the period 1984-94. Arrival of wind-borne diaspores on the site will presumably continue, but the artificial modification of the relevant seral stage, by sowing grass, makes its future contribution problematical.

Plantago major (Greater Plantain), a common ruderal species on severely disturbed productive land, was rare on the spoil both on and off middens.

Poa annua (Annual Meadow-grass) may survive as an ephemeral ruderal of severely-disturbed land, or a longerlived competitive ruderal of productive pastures (Grime, 1979). The records of Table IV illustrate its preference for middens where, avoided by Rabbits, it flowers. Rabbit 
scrapes on middens provide regeneration niches through continuing local disturbance to nutrient-enriched spoil.

Prunella vulgaris (Selfheal), a C-S-R strategist (Grime, 1979) of grassland and waste places mainly on basic soil (Clapham et al., 1987), became increasingly abundant on the spoil. Its rhizomes, stress-tolerance, competitive ability, and Rabbit-resistance, allowed it to spread, irrespective of midden boundaries ( $c f$. Table IV), after 1986 when it became established on the site. It flowered — on a midden — for the first time in 1991. Data published by Davis et al. (1993) suggest that addition of fertilizer 'chosen to simulate the effect of rabbit latrines' (with continued Rabbit access) slowed a decline in rooted frequency of $P$. vulgaris on a quarry floor. Selfheal is likely to become, and long remain, an important seeding and clonal component of the vegetation of the spatially heterogeneous spoil.

Ranunculus repens (Creeping Buttercup), recorded on one midden in the sample (see Table IV), is classified by Grime (1979) in the group of 'ruderal perennial herbs' which include Achillea millefolium and Agrostis stolonifera as colonists of bare soil. In the manner of these species, which survived long after sowing, the Buttercup is resistant to Rabbit-grazing. Although it is well-liked by Rabbits (Bhadresa, 1987), it was found on other middens, but not off them, and thus demonstrated both its resistance and its dependence on the midden habitat. No flowers were found until 1994; the continuance on the site of this widespread species seems assured as long as nutrient-rich, grazed patches remain.

Sagina procumbens (Procumbent Pearlwort) is a small ruderal, with a persistent seed-bank beneath the soil surface. Its seed-germination is inhibited by darkness (see Grime 1979); the species accordingly exploited temporary gaps, such as scrapes, in the sward of middens although it survived (less luxuriantly) elsewhere ( $c f$. Table IV). Its small size and prostrate habit probably make it unworthy of the attention of Rabbits. Nevertheless it is dependent on the middens for the nutrient-rich, moist compacted soil which it requires; its ecology contrasts with that of its congener $S$. apetala (Annual Pearlwort), which was found mainly off the middens.

Senecio jacobaea (Ragwort), a monocarpic, deeprooted ruderal species avoided by Rabbits, and able to persist on middens as ungrazed rosettes (see Fig. 4, S.j), receives special attention below.

Taraxacum officinale agg. (Dandelion) is described as a stress-tolerant competitor by Grime (1979). It is not dependent on Rabbits for its establishment on the spoil, and though said to be 'unfitted to withstand grazing' ( $c f$. Table VI), it produced the largest of all rosettes on middens. By 1994, inflorescences were frequent all over the spoil; nutrient stress away from middens may have been responsible for its earlier rarity. Dandelions increased in frequency following exclusion of Rabbits for one year in grassland in Suffolk (Bhadresa, 1987), where evidence for ingestion of the Dandelions by Rabbits was lacking.

Veronica serpyllifolia (Thyme-leafed Speedwell) contributed to cover primarily on one of the sample middens, and was present on its companion area in 1991 (see Table IV). It is a prostrate, creeping, stress-tolerant ruderal perennial, able to establish itself in grassland communities where flowering may be delayed until gaps arise. It showed no evidence of Rabbit-grazing. The comment (Clapham et al., 1987) 'often on rather moist ground' is in accord both with the midden-habitat, from which it might have spread clonally, and with a tendency for surface water to accumulate on the level microsite where it was recorded. This common, small herb 'behaves in many ways as an opportunist annual' (Boutin \& Harper, 1991); its niche will long remain in the damper parts of a site patronized by Rabbits. However, those Authors (ibid.) reported winter mortality of $20 \%$ and $50 \%$, respectively, in two grassland cohorts, with cold, burial by worm-casts, and slug-predation, offered as causes. Our plants were not refound in 1994 reflecting, perhaps, such mortality and the instability of immigrant populations where founding members are few.

\section{Demography of Ragwort ln the Study Area}

Ragwort (Senecio jacobaea) is the most conspicuous of the invasive plants on the spoil. It is also a pest (toxic to livestock) in neighbouring pastures. Large flowering specimens were much in evidence in the Summers of 1990-2, and small seedlings were always present. The mean number of Ragwort plants in a centrally-placed quadrat was slightly greater on the middens than on the companion areas in 1991, and significantly greater in 1992 (Table VII).

There was a site-specific constancy in the number of plants found in these years, although this was probably not due entirely to survival of particular rosettes (only $29 \%$ on middens and $9 \%$ on companion areas appeared to survive from one year to the next (see Table VII)); the general tendency for propagules to fall around a parent plant, and the specific ability of a damaged axis or even root fragments of Ragwort (see Meijden \& Waals-Kooi, 1979) to regenerate, might also be involved.

TABLE VII

Senecio jacobaea: Mean Values of Various Parameters on and off the Middens.

\begin{tabular}{llll}
\hline Parameter & Middens & Companion Areas & Significance \\
\hline 30 August 1991 data: & & & \\
A. Mean nr of individuals & $43.4[7.5]$ & $35.0[6.8]$ & $\mathrm{p}>0.05$ \\
B. Mean longest leaf length & $16.6[0.8] \mathrm{mm}$ & $7.7[0.3] \mathrm{mm}$ & $\mathrm{p}<0.001$ \\
C. Mean distance from centre & $85.4[1.3] \mathrm{mm}$ & $73.4[1.5] \mathrm{mm}$ & $\mathrm{p}<0.001$ \\
D. Nr of capitula & $43.8[21.5]$ & $25.7[3.2]$ & $\mathrm{p}>0.05$ \\
29 September 1992 data: & & & \\
A. Mean nr of individuals & $36.5[5.3]$ & $18.4[4.7]$ & $\mathrm{p}<0.05$ \\
$\quad$ Survival rate 1991-2 & $29 \%$ & $9 \%$ &
\end{tabular}

Key: A to C for plants at rosette stage; D for flowering plants. Statistical tests: unpaired t-test, except for A where a paired t-test was used. Standard errors in square brackets. Turnover rate $=100 \%$ - (number of surviving plants $1991-1992 \times 100 /$ total number of different individuals in 1991 and 1992). 
Some plants were found to survive as rosettes between May 1990 and September 1992; of these some grew, but just as many became smaller. This suggests the effects of nutrient deficiency (the 'arrested development' of Watt, 1981), and possibly of mechanical damage (nibbling and trampling), or even consumption of roots, by Rabbits (see Meijden \& Waals-Kooi, 1979). A positive relationship between rosette diameter and the onset of flowering was reported by those Authors; in any case, flowering of many individuals has been delayed on the middens for several years.

The average number of capitula per flowering specimen in August 1991 was greater on the middens than on the companion areas, as was the mean maximum leaf-length of rosettes. These results (with varying degrees of statistical confidence) are consistent with the hypothesis that middens provide more favourable sites for establishment and growth of Ragwort than areas 'unpatronized' by Rabbits. However, the midden sward is not uniformly hospitable to Ragwort: the average distance of seedlings from the centre was significantly greater for middens than for companion areas ( $c f$. Table VII), suggesting a negative influence on germination and establishment in the midden centres. Further evidence for this negative influence was obtained by dividing the quadrat into equal areas representing outer and inner zones of midden or companion area in different proportion ( $c f$. Fig. 2). Counts of seedlings yielded the pooled data of Table VIII: these show fewer plants than expected in the inner zones of middens, compared with the essentially random distribution in the companion areas.

\section{TABLE VIII}

Senecio jacobaea: Frequencies of Plants in two Quadrat-zones of Fig. 2.

$\begin{array}{ccc} & \text { Middens } & \text { Companion Areas } \\ \text { Inner zones } & 162[193] & 186[155] \\ \text { Outer zone } & 275[244] & 165[196]\end{array}$

Based on amalgamated data from 10 middens and 10 companion areas. Figures in square brackets are expected frequencies as used in chi-square calculations.

From these results a tenable hypothesis emerges that Ragwort may germinate, and become established more easily, in an ecotone bounding each midden, than in either the companion area or the centre of a midden. Individuals surviving these critical stages have access to richer soil and grow better near the centre of a midden, but this advantage may later diminish as the roots ( $c f$. Fig. $4, S . j$ ) enter a less nutrient-rich horizon.

\section{Other Plant Species Immigrating in the First Decade}

Some of the 40 immigrant flowering-plant species found by searching the spoil at the end of the first decade have sufficiently clear edaphic requirements to be regarded as indicators of various soil conditions. Many species could be found both on and off middens, as had been illustrated in 1990 ( $c f$. Table IV) when a similar search had yielded a total of about 20 species. A number of the species found in 1994 have been selected to illustrate their ecological relationships with the Rabbits.

A phanerogamic indicator of elevated soil nitrogen is Urtica dioica (Stinging Nettle), which was infrequent on the spoil before 1992. The Nettle is a competitive rudera1 species generally, but not entirely (see Lockley, 1976), avoided by Rabbits; the presence of its erect stems (with damaged apices) on a midden from 1988 onwards indicated not only the locally high nutrient status of the soil but also the Rabbits' avoidance of old material. Depauperate Stinging Nettles were found scattered elsewhere on the spoil by 1994 .

Cryptogamic indicators of soil enrichment include Brachythecium rutabulum and Peltigera membranacea, the latter being a foliose lichen associated with Rabbit dung (M.R.D. Seaward pers. comm.) and found on middens in 1994.

Two species, Cirsium palustre (Marsh Thistle) and Deschampsia cespitosa (Tufted Hair-grass), revealed areas where water was retained after heavy rain; the first (damaged) inflorescence of the Thistle was observed in 1994. Both species produce soil seed-banks (Grime, 1979), and when the site develops a closed vegetation cover, both may be favoured by Rabbit activity. Well-developed rosettes of the Thistle were found in 1994, scattered over the site, when tufts of $D$. cespitosa were found for the first time. The latter had been heavily grazed both on and off the middens, suggesting that this highly palatable, perennial competitor was being controlled by the 'normal' and 'casual' grazing of Rabbits.

Cirsium arvense (Creeping Thistle), a competitive ruderal-perennial herb and a 'very troublesome weed' (Clapham et al., 1987), flowered abundantly each year, between 1984 and 1994, on disturbed grassland nearby ('Ad' on Fig. 1), and latterly on parts of the sown area where its performance indicated disturbed subsoil at or near the spoil surface; it was present only as small, shortlived rosettes throughout the remainder of the spoil, where it produced infrequent inflorescences which were all Rabbit-damaged in 1994.

Tussilago farfara (Coltsfoot) was likewise present as generally small, scattered, non-flowering plants, but by 1994 one part of the population, on a spoil scree ( $c f$. Fig. 1), was more luxuriant than the remainder. The cause of this enhanced performance was not evident, although better soil drainage on this steep area may be involved.

Rhizomatous ruderal-perennial species such as $C$. arvense and $T$. farfara occur as seedlings or small plants during initial colonization of bare ground (Grime, 1979), and these would undoubtedly have spread widely had the soil been generally fertile. Rabbit middens might provide a suitable level of nutrients for such species, but there is no evidence that either is favoured on middens. In the absence of disturbance, both species are expected to be outcompeted in the long-term (see Grime, 1979).

Whilst some immigrant species do not indicate dependence on an overriding edaphic factor, a degree of initial dependence on the Rabbits may be hypothesized for some others. Thus Euphrasia confusa (Eyebright), a species nibbled, but widespread, in grassland as described by Watt (1981), was first found, flowering, on several adjacent middens only, in 1992. The very local abundance of this annual hemiparasite* suggests that at least one individual flowered, unobserved, and produced seeds in a previous year. The survivorship of seedlings of this turf-compatible species, parasitic on the roots of grasses, is likely to be enhanced by an abundance of grass roots; its colonization of the spoil has been facilitated by host grass(es) grazed to a sward, and thus, probably, by the Rabbits.

* Partially parasitic in deriving water and mineral nutrients from a host but photosynthesizing its own organic foods. - Ed. 
The small stoloniferous C-S-R strategist (vide Grime, 1979) Veronica chamaedrys (Germander Speedwell) was found on a few middens after 1991. Although it was shown to be a selected food plant of Rabbits, it was found, by Bhadresa (1987), to decrease in grassland exclosures. Its lowly habit (see Fig. 4, V.c) renders it resistant to Rabbitgrazing; middens have provided surrogate, grazed grassland. Compared with $V$. serpyllifolia, Boutin \& Harper (1991) discovered its marked failure in seed set. If middens have so far provided the only suitable niche for this species on the spoil, its vegetative reproductive strategy through clonal fragmentation is unlikely to facilitate its spread until a more complete sward has formed.

Some herbaceous colonists in open vegetation may be little affected by Rabbits. One such plant, unlikely to attract Rabbits on account of its insubstantial appearance, is Linum catharticum (Fairy Flax). It is described as a stresstolerant ruderal by Grime (1979), and is said to be an annual in most texts. However, it is described as biennial by Keizer et al. (1985), and is characteristic of calcareous grassland (Clapham et al., 1987). It flowered, on middens, for the first time in 1991, and has since been found flowering generally on the spoil. An Appendix to the paper by Davis et al. (1993) records no change in the occurrence of this species in 36 plots on a quarry floor over a period of five years despite different regimes of Rabbit access. As a colonizer of gaps it is likely to persist.

Bellis perennis (Daisy) is, by virtue of its rosette habit and its short, procumbent, branched rootstock, resistant to grazing. Scattered, mostly non-flowering, rosettes had been found, both on and off the middens, by 1992. Flowering specimens were frequent on the spoil by 1994, and abundant on a nearby area of subsoil, of similar aspect and slope (part of 'Ah' on Fig. 1), which had been exposed for only three years. The strategy of this species appears to be that of a ruderal-perennial. Exclusion of Rabbits did not affect its occurrence in quarry-floor vegetation in the fiveyears' experiment of Davis et al. (1993). Its survival is assured on the site as long as grasses are prevented from exerting their full potential for dominance. Flowering can be prevented through removal of the flower-buds by Rabbits (see Thomas, 1963), but copious invasions by seeds (botanically fruits) of this common species may negate any influence of local persistance and/or flowering on plant numbers.

Primula veris (Cowslip), a stress-tolerant ruderal (Grime, 1979), flowered on the spoil from 1991 onwards. It was, according to Lockley (1976), one of several species that were left severely alone even by malnourished Rabbits. But Thomas (1960) mentions it as one of the species contributing to the show of downland flowers after Rabbit grazing was eased - suggesting vulnerability of its inflorescences to Rabbit-grazing. As a spectacular species of calcareous meadows and pastures, its presence and relative immunity from Rabbit attack make it one of the most desirable herbaceous species yet to colonize the spoil.

\section{Desirable Potential Immigrant Species Not Found in the First Decade}

The establishment of a few representatives of any immigrant plant species illustrates the presence of a suitable niche (vide Ash et al., 1994), and may result in a later abundance provided grazing animals do not prevent seed- set. As Davis et al. (1993) and Hambler \& Speight (1995) have pointed out, the composition of vegetation (from the conservation point of view) is at least as important as species-richness. An increase in the number of immigrant species on the site between 1985 and 1994, is illustrated by the series of counts - $0,10,25,40$ - made at intervals of three years. These suggest a progress towards the attainment of 'richness'. However, the vegetation remained largely open, at the end of the first decade, when the potential species-density could scarcely have reached a maximum.

'Desirable species', in our context, are early successional calcicolous herbs and certain trees or sub-trees. We are aware of the conservation limitations of 'the devastated landscapes of calcareous grasslands, where forests have been reduced to a thin smear of life between rock and sun' (Hambler \& Speight, 1995). We would expect that the largely herbaceous vegetation of the site will eventually be succeeded by shrubs, and deciduous sub-trees and trees including Corylus avellana (Hazel) and Fraxinus excelsior (Ash) - both already planted. These are the sequential dominants of calcareous soils during the late stages of succession in the region, Hazel being a sub-tree that is now seriously threatened in Britain (according to Rackham, 1986). It formerly yielded a crop of nuts on the quarry site, and surely deserves conservation.

A number of desirable herbs which were abundant locally could not be found on the spoil. One such species was Briza media (Quaking Grass). It occurs preferentially on well-drained, north-facing limestone grassland slopes (Grime \& Lloyd, 1973), but was not found on the site during the first decade. Its absence, despite the apparent suitability of the steeper slopes, reflects the unpredictable, random element in primary colonization.

Other such species occurred in areas of small extent within one kilometre of the site, but separated from it by topographical and industrial barriers. Examples include Gentianella amarella (Autumn Gentian), on an old quarryfloor; Origanum vulgare (Wild Marjoram), on a roadside verge; and various orchids, including Ophrys apifera (Bee Orchid) on embankments. They all produce numerous small seeds, which confer the 'high vagility' (i.e. capability to disperse) that is characteristic of quarry colonists (Usher, 1979). The small size of the nearest source populations is a likely explanation of the absence of these, and of several other herbaceous calcicoles whose local populations exist precariously amongst the active quarrying, landfill, and planted-tree screens of the area.

Some desirable species were apparently exterminated from the quarried area during the 19th century (see Rotheray, 1900). They include Primula farinosa (Bird'seye Primrose), Dactylorhiza incarnata (Early Marsh-orchid), and Anthyllis vulneraria (Kidney-vetch). Although suitable habitats for such species are likely to exist on the spoil, their re-arrival by natural means is unforeseeable even though 'geographical' isolation of industrial sites from species populations of ecologically apropriate wild plants does not preclude such colonization (Gemmel \& Crombie, 1976). However, distance and rarity of sources, and any lack of abundance at such sources, must each decrease the likelihood of a species colonizing, or recolonizing, a site. Translocation, especially of desirable local species into open vegetation such as that on the spoil, might be possible - and more excusable than sowing commercial wildflower mixtures of unknown provenance. 


\section{Rabbit Behaviour: Its Relevance to Spoil Rehabilitation}

If a worked-out quarry-site is to be rehabilitated through encouragement of a seral, species-rich plant community, management of the herbaceous component through grazing mammals is desirable. Rabbits may, as here, be the only available mammal of at-all suitable size, and their effectiveness must depend directly upon their numbers, and inversely upon the coarseness of the developing vegetation. It must also depend upon their behaviour, which is not altogether predictable. Midden usage may be predictable, however. Numerous middens were well established on the spoil when thirty were marked for formal observation in 1990. All were still in use in 1994. As they had probably been initiated in the 1980 s, a decade of use, thus far, is a reasonable assumption. The middens provided a habitat favouring some plants and invertebrates (Dixon \& Hambler, 1993) in relation to the remainder of the spoil. Rabbits have thus initiated a mosaic of plant and animal habitats on the spoil, and have contributed, even within a single midden, to spatial heterogeneity which can affect the demography of individual plant species, as exemplified by that of Senecio jacobaea.

Loss of Rabbits from established grassland has been shown to be a potent generator of floristic change, though initial abundance of flowers may be observed (Thomas, 1960). Such observations suggest a flowering of species which have persisted vegetatively. However, changes in the percentage frequencies of species may appear in exclosures in periods as short as one year. Such changes have been related to feeding preferences which are not constant (see Bhadresa, 1987), and are undoubtedly related to optimal foraging behaviour in diverse circumstances.

Although Rabbits made grazed and trampled runs, littered with pellets, through the tall grassy communities bordering the spoil ( $c f$. Fig. 1), they appear to have had little impact on the overall structure of such vegetation. Rabbit feeding of two types was described by Southern (1940), namely normal and casual. The first is described as true cropping on areas that are already grazed hard; the animal crops by moving its head in a semicircle before moving forward for a short distance; it is relatively unselective of food-plants, and is stimulated to defaecate. We infer that this is what occurs on the midden swards. Such grazing also occurs as Rabbits make brief pauses along regular compacted, pellet-littered runs along the spoil contours.

In contrast, casual grazing, when the Rabbit's appetite is less demanding, involves a greater degree of choice: Rabbits investigated and damaged individual plants, including young trees, that were conspicuous in open vegetation on the spoil. This makes it likely that any rarer herbaceous introductions and immigrants, and especially juvenile woody specimens, will not survive without protection on such a site. Casual grazing was exemplified when Rabbits were attracted to small groups of unprotected Anthyllis vulneraria seedlings and destroyed them, while protected plants survived and flowered. Upstanding or isolated inflorescences of unpalatable forbs were bitten, although localized monospecific stands of the common ' $r$ selected' ruderal Cirsium arvense escaped such control where subsoil, rather than spoil, was exposed.

Of the eight forbs sown in 1984, none had flowered by 1993, although remnants of some cohorts persisted. This failure, and the absence, or subjectively apparent decline in frequency, of some appears to be related more to Rabbit behaviours than to plant strategies or edaphic tolerances. Middens were interpreted by us as a food-resource, maintained by the Rabbits through behavioural feedback. Not only do the Rabbits graze the aerial parts of plants, they also make scrapes - which are, according to Southern (1940), definitely for obtaining underground plant-parts. Scrapes began appearing in middens a few years after the closed sward developed (Fig. 5). This behavioural trait produces gaps in the plant cover which offer both germination sites for immigrant diaspores and surfaces of relatively rich soil into which stoloniferous species, already present, may expand.

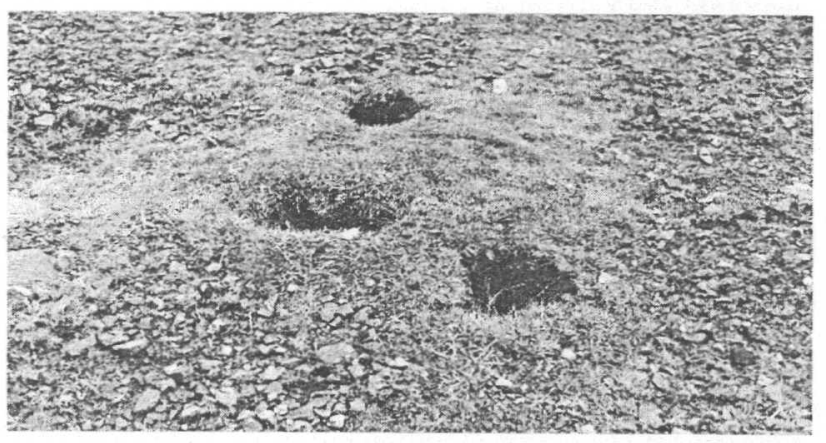

FIG. 5. Midden showing elevation above the spoil's surface, 'normally' grazed sward, and three Rabbit's scrapes each approximately $15 \mathrm{~cm}$ in diameter.

\section{General and Practical Conclusions}

We have demonstrated the overriding influence of Rabbits in the earliest years of a spoil rehabilitation project. This influence was, at first, localized through the production of 'normally' grazed middens, although any conspicuous plant that was situated away from the middens was also liable to be damaged; this was the most likely cause of decline of several sown species, and could be responsible for hindering immigration of species of which the propagules do not arrive in sufficient numbers to overcome the Rabbits' vigilance in attending to, and often attacking, anything at all unusual or conspicuous.

It has been possible to relate the performances of some plant species, whether planted or immigrant, to published autecological information, to the theoretical concept of 'strategy', and to observations on Rabbit behaviour recorded in the literature. This behaviour may be postulated with some confidence as the main factor affecting survival and/or reproduction of most species.

Industrial wastes or entire disused quarries are in some sense 'islands' open to colonization from an external 'pool' of species - see Usher (1979) and Ash et al. (1994). But there can be no predictive and practical application of classical 'island' theory regarding colonization, even of a single waste-heap - the species pool is illusory, with neither spatial nor floristic integrity. As Usher (1979) suggests, there is a random element in colonization: it is self-evident that the number of species will rise initially on any such site, given only the sources, and that the propagules of common, wind-dispersed ruderal species will, more or less persistently, arrive in large numbers. Such invasions can be described as 'saturating', with the potential of every micro-habitat thus explored. Several of the species on our site, including Senecio jacobaea, fall into this category. 
Diaspores of more-desirable 'r-selected', stress-tolerant calcicoles, such as various Orchidaceae, will inevitably reach a quarry-site; Rabbit behaviour and numbers, as well as the intensity of the seed-rain, will influence the outcome. Several such species having local populations failed to immigrate over a period of ten years. Rabbits may prevent initially rare potential founder individuals from reproducing, and they will certainly hinder the attainment of ecesis and subsequent full establishment of desirable ' $\mathrm{K}$ selected' trees or sub-trees such as Hazel.

Do the colonizing species of quarries share any ecological characteristics? We have shown that a single northfacing spoil slope has provided a variety of habitats, including both damp and drier areas — and, importantly here, also middens which are themselves not uniform. A further type of habitat (adding to the variety of ecological microsites for plant establishment) was in process of formation towards the end of the decade - groups of Rabbit burrows with accompanying mounds of spoil, and of excavated 'ancient' soil. Accordingly, neither the ecological characteristics, nor the strategies of the colonists, have been uniform, and the performances of some including all of the sown species and some immigrants have been sub-optimal. This reflects the tolerance model of colonization described by Usher (1979) — an initial scramble into an empty environment in which the numbers of propagules of two expected grass colonists had been augmented by sowing.

In his hypothetical reconstruction of the succession in a chalk quarry, Usher (1979) proposed a dicotyledon-rich 'colonizing species stage', and a later 'grassland stage'. The elimination of low-growing dicotyledons would be more rapid in the absence of Rabbits, when tall Arrhenatherum elatius grassland could develop. This species was present in fairly high frequency, even in the first stage recorded by Usher (ibid.), but, surprisingly, it was not found on our site during the first ten years of our study.

Midden-producing behaviour has advantages for reclamation where shortage of nitrogen limits the performance even of a stress-tolerant grass. However, "normal grazing' maintains a sward in which only distasteful forbs can complete their life-cycles, while 'casual grazing' may eliminate unprotected trees and shrubs, and also scarce, but desirable, colonizing or introduced herbaceous species.

Our work thus demonstrates that, in an attempt to encourage the assembly of a seral grassy community on a nutrient-poor site, access by Rabbits may initially be helpful. However, the likely consequences of certain behaviours, especially upon survival of rare, random arrivals, and of young trees, must be appreciated. Management will be required of vegetation such as that we have described. As Usher (1979) suggests '... the end point of succession ... is frequently different [from] what might have been predicted for a non-quarried environment'. The route to that end-point is likewise uncertain; but flexible management, through manipulation of Rabbit populations or manipulation of Rabbit-access, as the most desirable route becomes evident, may be a preferred option.

\section{ACKNOWLEDGEMENTS}

We thank Tilcon Limited for continued interest in our work, and for assistance with expenses. Thanks are due to Stewart Davidson for the figures reproduced here. We are grateful to an anonymous Referee and our ever-vigilant Editor for some particularly helpful suggestions.

\section{SUMMARY}

Rabbits (Oryctolagus cuniculus) have influenced a sown pioneer grassland on limestone quarry spoil from its outset. They have been responsible for middens characterized by a distinct microspatial assemblage of plant species, in which common mesic species are favoured. They have benefited conservation through producing spatial heterogeneity of the spoil surface - thus increasing the number of available ecological niches. They have also mediated an importation of plant nutrients so gradual that competitive ruderal species have (with the exception of Ragwort, Senecio jacobaea) not been encouraged, whilst some desirable 'rabbit-resistant' species have become established particularly on the middens.

'Normal grazing' is a behavioural pattern which can maintain a sward, even when potentially dominating mesic species become established. However, 'casual grazing', and browsing, of conspicuous or rare plants, is likely to be disadvantageous. Manipulation of intrinsically unpredictable seral quarry floras through interference by Rabbit populations, or with Rabbit-access, may be an option on such sites.

\section{REFERENCES}

Allen, S.E., Grimshaw, H.M., Parkinson, J A \& Quarmby, C. (1974). Chemical Analysis of Ecological Materials. Blackwell Scientific Publications, Oxford, England, UK: $x+565$ pp., illustr.

Anderson, P. \& Romeril, M.G. (1992). Mowing experiments to restore a species-rich sward on sand dunes in Jersey, Channel Islands, GB. Pp. 219-34 in Coastal Dunes Geomorphology, Ecology and Management (Eds R.W.G. CARTER, T.G.F. CuRTIS \& M.J. SCHEEHY-SKEFFINGTON The Netherlands: [not available for checking].

Ash, H.J., Gemmell, R.P. \& Bradshaw, A.D. (1994). The introduction of native plant species on industrial waste heaps: a test of immigration and other factors affecting primary succession. Journal of Applied Ecology, 31(1), pp. 74 -84, illustr.

BHADRESA, R. (1987). Rabbit grazing studies in a grassland community using faecal analysis and exclosures. Field Studies, 6, pp. 657-84, illustr.

Boutin, C. \& HARPER, J.L. (1991). A comparative study of the population dynamics of five species of Veronica in natural habitats. Journal of Ecology, 79(1), pp. 199-222, illustr.

Clapham, A.R., Tutin, T.G. \& Moore, D.M. (1987). Flora of the British Isles - 3rd edn. Cambridge University Press, Cambridge, England, UK: xxviii + 688 pp., illustr.

DAvis, B.N.K., LAKHANI, K.H. \& BROWN, M.C. (1993). Experiments on the effects of fertilizer and rabbit grazing upon the vegetation of a limestone quarry floor. Journal of Applied Ecology, 30(4), pp. 615-28.

DixON, J.M. \& HAMBLER, D.J. (1993). Wildlife and conservation: Rabbit middens on seeded limestone quarry spoil. Environmental Conservation, 20(1), pp. 65-73, illustr.

Furness, S.B. \& GRIME, J.P. (1982). Growth rate and temperature responses in bryophytes - I, An Investigation of Brachythecium rutabulum. Journal of Ecology, 70(2), pp. 513-23, illustr.

Gemmell, R.P. \& CROMBIE, S.A. (1976). Management of waste tips for enhancement of landscape quality. Landscape Research News, 1(2), pp. 10-1, illustr.

Gillham, M.E. (1955). Ecology of the Pembrokeshire Islands, Part III: The effect of grazing on the vegetation. Journal of Ecology, 43(1), pp. 172-206, illustr.

Grime, J.P. (1979). Plant Strategies \& Vegetation Processes. John Wiley \& Sons, Chichester, England, UK: xi + 222 pp., illustr.

GRIME, J.P. \& LLOYD, P.S. (1973). An Ecological Atlas of Grassland Plants. Arnold, London, England, UK: 192 pp., illustr.

HAMBLER, C. \& SPEIGHT, M.R. (1995). Biodiversity conservation in Britain _ science replacing tradition. British Wildlife, 6, pp. $137-47$, illustr.

Hambler, D.J., Dixon, J.M. \& CotTon, D.E. (1990). The relative potentials of six grass cultivars for rehabilitation and stabilization of a limestone quarry spoil-bank. Environmental Conservation, 17(2), pp. 149-56, illustr.

(Concluded on page 322) 
MATTAR, A. (1991). Coastal resources management: the Singapore experience. Pp. 83-90 in Proceedings, Managing ASEAN's Coastal Resources for Sustainable Development (4-7 March, Manila and Baguio). (Eds T.E. ChUA \& L.F. SCURA). International Centre for Living Aquatic Resources Management, Manila, Philippines: $x+370$ pp., illustr.

MeITH, N. \& HELMER, R. (1993). Marine environment and coastal resources in Southeast Asia: a threatened heritage. Pp. 260-94 in Ocean Yearbook 4 (Eds E.M. BORGHESE \& N. GINSBURG). University of Chicago Press, Chicago, Illinois, USA: v + 415 pp.

Ministry of THE EnVIRONMENT (1992). The Singapore Green Plan: Towards a Model Green City. Times Editions, Singapore: 93 pp., illustr.

Ministry OF THE ENVIRONMENT (1993). The Singapore Green Plan - Action Programmes. Times Editions, Singapore, 80 pp., illustr.

MinISTRY OF INFORMATION AND THE ARTS (1994). Singapore Facts and Figures. Singapore National Printers Ltd, Singapore: 204 pp., illustr.

MinISTRY OF LAW (1994). Singapore Street Directory. Pacific Trade Press Pte Ltd, Singapore: 558 pp., illustr.

Ministry of NAtional Development (1993). Work Group on Nature Conservation, Report 5. Unpublished [typeser.] Report, Ministry of National Development, Singapore: 37 pp., illustr.

NATURE CONSERVATION WORKGROUP (1993). The Singapore Green Plan: (Workgroup 5: Nature Conservation.) [Unpublished Report] Ministry of National Development, Singapore: $32 \mathrm{pp}$.

PARISH, D. \& Wells, D.R. (1984). Interwader Report 1983. Interwader Publication No. 1, Kuala Lumpur, Malaysia: 56 pp., illustr.

Pirazzoli, P.A. (1991). World Atlas of Holocene Sea-level Changes. (Elsevier Oceanography Series, Nr 58.) Elsevier, London, England, UK: ix + 300 pp., illustr.

Polunin, I. (1987). Plants and Flowers of Singapore. Times Editions, 422 Thomson Road, Singapore 1129, Singapore: 160 pp., illustr.

Polunin, N. \& Worthington E.B. (1990). On the use and misuse of the term 'ecosystem'. Environmental Conservation, 17(1), p. 274.

Republic of Singapore Yacht Club (cited as RSYC), Singapore Institute of Biology and Singapore Underwater Federation (1991). Singapore Reef Survey and Conservation Proiect: A Proposal for the Conservation of Coral Reefs in Singapore, Singapore: $42 \mathrm{pp}$., illustr.

SANDlund, O.T., Hindar, K. \& BRown, A.H.D. (1992). Conservation of Biodiversity for Sustainable Development. Scandinavian University Press, Oslo, Norway: vii +321 pp., illustr.

SAVAGe, V. (1992). Human-environment relations: Singapore's environmental ideology. Pp. 187-217 in Imagining Singapore

[Concluded from page 334]

Jones, D.A. \& TuRkington, R. (1986). Lotus corniculatus L. (Biological Flora of the British Isles Nr 163.) Journal of Ecology, 74(4), pp. 1185-1212, illustr.

KEIZER, P.J., TOOREN, B.F. VAN \& DURING, H.J. (1985). Effects of bryophytes on seedling emergence and establishment of shortlived forbs in chalk grassland. Journal of Ecology, 73(2), pp. 493-504, illustr.

KLINKHAMER, P.G.L. \& Jong, T.J. De (1993). Cirsium vulgare (Savi) Ten. (Biological Flora of the British Isles Nr 176.) Journal of Ecology, 81(1), pp. 177-91, illustr.

LockLey, R.M. (1976). The Private Life of the Rabbit. Andre Deutsch, London, England, UK: 152 pp., illustr.

MEIJDEn, E. VAN DER \& WAALS-KoOI, R.E. VAN DER (1979). The population ecology of Senecio jacobaea in a sand dune system, I: Reproductive strategy and the biennial habit. Journal of Ecology, 67(1), pp. 131-53, illustr.

Rackham, O. (1986). The History of the Countryside. J.M. Dent \& Sons, London, England, UK: xvi + 445 pp., illustr.

RinCON, E. \& GRIME, J.P. (1989). Plasticity and light interception by six bryophytes of contrasted ecology. Journal of Ecology, 77(2), pp. 439-46, illustr.

ROTHERAY, L. (1900). Flora of Skipton \& District. Craven Naturalists \& Scientific Association, Skipton, England, UK: vii + 133 + iv pp.
(Eds K.C. Ban, A. Pakir \& C.K. Tong). Times Academic Press, Singapore: viii + $362 \mathrm{pp}$.

Singapore National Report to United Nations Conference on ENVIRONMENT AND DEVELOPMENT (1992). Inter-Ministry Committee for the UNCED Preparatory Committee, Singapore: 69 pp., illustr.

Straits Times, 26 February 1989. “Government will prevent dump site from polluting sea'. Singapore: $43 \mathrm{pp}$.

STRAITS TImes, 16 June 1993. 'Nature Society wants Khatib Bongsu and Senoko conserved'. Singapore: $42 \mathrm{pp}$.

Straits Times, 12 November 1993. 'It will cost $\$ 130 \mathrm{~m}$ to find Sakeng alternative'. Singapore: $48 \mathrm{pp}$.

STRAITS Times, 19 March 1994. 'No to Senoko as bird sanctuary people's needs more pressing'. Singapore: $42 \mathrm{pp}$.

Straits Times, 28 March 1994. 'Nature can co-exist with development'. Singapore: $43 \mathrm{pp}$.

Straits Times, 13 April 1994. 'Nature conservation: Government taking balanced approach'. Singapore: $45 \mathrm{pp}$.

StRAITS Times, 19 April 1994. 'Growth and nature conservation: Why can't there be compromise?'. Singapore: $41 \mathrm{pp}$.

SwAN, S.B. STC. (1971). Coastal geomorphology in a humid tropical low-energy environment: The islands of Singapore. Journal of Tropical Geography, 33, pp. 43-61.

TAN, I.K. (1966). The Fishing Settlements of Pulau Semakau. Unpublished [typescr.] BA (Hons) thesis, Department of Geography, National University of Singapore, Singapore: iii + 35 pp., illustr.

Tham, A.K. (1973). The Sea. Pp. 140-9 in Animal Life and Nature in Singapore (Ed. S.H. CHUANG). Singapore University Press, Singapore: viii + 302 pp., illustr.

WEE, Y.C. (1964). A note on the vegetation of Singapore. Malay Forester, 27, pp. 257-66.

WEE, Y.C. \& CORLETT, R.T. (1986). The City and the Forest: Plant Life in Urban Singapore. Singapore University Press, Singapore: viii + 186 pp., illustr.

WONG, P.P. (1969). The changing landscapes of Singapore. Pp. 20-51 in Modern Singapore (Ed. J.B. OoI). Singapore University Press, Singapore: vi +211 pp., illustr.

Wong, P.P. (1985). Artificial coastlines: the example of Singapore. Zeitschrift für Geomorphologie, 57, pp. 175-92, illustr.

WORLD COMMISSION ON ENVIRONMENT AND DEVELOPMENT [cited as WCED] (1987). Our Common Future. Oxford University Press, Oxford, England, UK: vii +400 pp.

YAP, L.H. (1986). Land Resource in Singapore: A Study in Resource Scarcity. Unpublished [typescr.] BA (Hons) thesis, Department of Geography, National University of Singapore, Singapore: $v+$ 87 pp., illustr.

SMith, A.J.E. (1980). The Moss Flora of Britain and Ireland. Cambridge University Press, Cambridge, England, UK: vi +706 pp., illustr.

SOUTHERN, H.N. (1940). Ecology and population dynamics of the wild rabbit (Oryctolagus cuniculus). Annals of Applied Biology, 27, pp. 509-25, illustr.

TANSLEY, A.G. (1949). The British Islands and Their Vegetation Vol. II. Cambridge University Press, Cambridge, England, UK: v-xxviii + 487-930 pp., illustr.

Thomas, A.S. (1960). Changes in vegetation since the advent of myxomatosis. Journal of Ecology, 48(2), pp. 287-306, illustr.

ThомAS, A.S. (1963). Further changes in vegetation since the advent of myxomatosis. Journal of Ecology, 51(1), pp. 151-86.

TiEndEREN, P.H. VAN \& TOORN, J. VAN DER (1991). Genetic differentiation between populations of Plantago lanceolata, II: Phenotypic selection in a transplant experiment in three contrasting habitats, Journal of Ecology, 79(1), pp. 43-59, illustr.

TOOREN, B.F. van, HeRTOG, J. DEN \& VerkaAR, H.J. (1988). Cover, biomass and nutrient content of bryophytes in Dutch chalk grasslands. Lindbergia, 14, pp. 1-8, illustr.

USHER, M.B. (1979). Natural communities of plants and animals in disused quarries. Journal of Environmental Management, 8, pp. 223-36, illustr.

WATT, A.S. (1981). A comparison of grazed and ungrazed Grassland A in East Anglian Breckland. Journal of Ecology, 69(2), pp. $499-508$, illustr. 